\title{
Cytotoxic activity, apoptosis induction and cell cycle arrest in human breast cancer (MCF7) cells by a novel fluorinated tetrahydro-[1,2,4]triazolo[3,4- a]isoquinolin chalcones
}

Magda F. Mohamed ( $\sim$ magdafikry85@yahoo.com )

Cairo University Faculty of Science

Nada S. Ibrahim

Cairo University Faculty of Science

Sherif Abdelaziz lbrahim ( $\square$ isherif@sci.cu.edu.eg)

Cairo University Faculty of Science

May A El-Manawaty

National Research Centre

Salwa M. El-Hallouty

National Research Centre

Hamdi M. Hassaneen

Cairo University Faculty of Science

Ismail Abdelshafy Abdelhamid ( $\nabla$ ismail@sci.cu.edu.eg)

Cairo University https://orcid.org/0000-0003-1220-8370

\section{Research Article}

Keywords: Fluorinated [1, 2, 4]triazolo[3,4-a]isoquinoline chalcones, breast cancer, DNA fragmentation, Apoptosis, molecular docking

Posted Date: May 18th, 2021

DOl: https://doi.org/10.21203/rs.3.rs-496965/v1

License: (c) (i) This work is licensed under a Creative Commons Attribution 4.0 International License. Read Full License

Version of Record: A version of this preprint was published at Polycyclic Aromatic Compounds on December 13th, 2021. See the published version at https://doi.org/10.1080/10406638.2021.2014535. 


\section{Abstract}

A series of halogenated chalcones (3-8) was synthesized and confirmed by several spectral tools. The cytotoxic effect of this series was tested against a panel of different cancer cell lines (MCF7, A549, HCT116, and PC3). Our MTT assay results revealed that chalcone 8 had the potent cytotoxic activity against all tested cancer cell lines except A549 cells, which were more sensitive to chalcone 7 relative to the positive control treated with doxorubicin. Chalcone $\mathbf{8}$ showed the least cytotoxic activity against the normal epithelial cell line RPE-1 and the lowest $\mathrm{IC}_{50}$ at $10.96 \mu \mathrm{M}$ relative to the $\mathrm{IC}_{50}$ of the chemotherapeutic drug doxorubicin at $12.8 \mu \mathrm{M}$ against the human breast cancer cell line MCF7. Molecular docking studies showed a good interaction of chalcone 8 with the active site of histone demethylase (PLU-1/ JARID1B) and Carboxy-terminal binding protein1 (CtBP1) proteins. Mechanistically, chalcone $\mathbf{8}$ induced cell cycle arrest at G2/M phase and apoptosis as assessed by flow cytometry, as well as DNA fragmentation in MCF7 cells. Chalcone 8 upregulated mRNA expression levels of the apoptotic genes BAX, p53, and Caspase-7, Caspase-8, and Caspase-9, whereas mRNA expression levels of the antiapoptotic gene Bcl2, metastasis-related gene matrix metalloproteinase 1, and the autophagic markers ATG5 and LC3B were downregulated as quantified by qPCR.

\section{Introduction}

Breast cancer is the second leading cause of cancer-related death among females worldwide with approximately 1.67 million new cancer cases (25\% of all cancer cases) [1]. The currently available treatments used for breast cancer include surgery and/or radiotherapy and adjuvant chemo- or hormone therapies [2]. Despite the great current efforts to control this devastating disease, its incidence is estimated to rise in the coming years[3]. Thus, innovative therapies are urgently needed for breast cancer. Chalcones (1, 3-diphenyl-2-propene-1-one) are one of the important classes of anticancer agents that have a promising effect against breast cancer [4]. They are the precursors of flavonoids and isoflavonoids and are found abundantly in edible plants [5]. They show a wide variety of activities, including anticancer [6], anti-inflammatory [7], and antimicrobial [8] activities. Several modifications on the chalcone nucleus have been done including methoxy, hydroxyl, and amino groups as substituents with a promising anticancer activity [9]. Halogenated chalcones showed an enhanced anti-proliferative activity including arresting of the cell cycle, induction of apoptosis, and multidrug resistance (MDR) reversal activity $[9,10]$. These findings prompted us to synthesize a novel series of halogenated chalcones and evaluate their cytotoxic activity against cancer cells with deciphering the underlying molecular mechanism of their action.

\section{Results And Discussion 2.1. Synthetic chemistry}

To expand our previous findings in the context of our interest in $C$ - $C$ bond formation reactions[11-13], as well as in the synthesis of bioactive compounds[14-18], we synthesized herein a novel series of 
halogenated chalcones and evaluated their cytotoxic activities against cancer cells. Claisen-Schmidt condensation of 3-acetyl-1-aryltetrahydro-[1, 2, 4]triazolo[3,4-a]isoquinoline 1[19, 20] with the mole equivalents of 4 -fluorobenzaldehyde 2 in the presence of $20 \% \mathrm{KOH}$ solution as a basic catalyst resulted in the formation of the corresponding fluorinated $[1,2,4]$ triazolo[3,4-a]isoquinoline chalcones $\mathbf{3}-\mathbf{8}$ (Scheme 1). The constitutions of the synthesized chalcones were confirmed by examining their spectral data.

\subsection{Anti-proliferative effect of Novel fluorinated $[1,2,4]$ triazolo [3,4-a] isoquinoline chalcones}

The anticancer activity of the synthesized compounds was studied against breast, lung, colon, and prostate cancer cells, including MCF7, A549, HCT116, and PC3, respectively, and the normal human retinal epithelial cell line RPE-1. As shown in Table 1 and Fig. 1, all tested compounds showed cytotoxic effects against all cancer cell lines used with an $\mathrm{IC}_{50}$ ranging from $10.96 \mu \mathrm{M}$ to $89.21 \mu \mathrm{M}$. Chalcone 8 displayed the lowest IC $_{50}$ against MCF7, HCT116, and PC3 cells at $10.96 \mu \mathrm{M}, 24.25 \mu \mathrm{M}$, and $29.88 \mu \mathrm{M}$, respectively relative to the chemotherapeutic drug doxorubicin with $\mathrm{IC}_{50}$ at $12.8 \mu \mathrm{M}$. Interestingly, chalcone 8 exhibited a cytotoxic effect against normal cell line RPE-1 with the highest $\mathrm{IC}_{50}$ of $137.5 \mu \mathrm{M}$. The $\mathrm{IC}_{50}$ of Chalcone 7 against the $\mathrm{A} 549$ cell line was $15.59 \mu \mathrm{M}$. The most potent activity of chalcone 7 and 8 against A549 and MCF7 cells was observed, respectively. This may be attributed to the presence of halogen substituents, which is consistent with previous studies $[9,10]$. Therefore, we will focus on the effect of chalcone $\mathbf{8}$ on MCF7 cells on the subsequent experiments.

Table 1. The $I_{50} \pm S D$ values of the halogenated chalcone derivatives 3-8 and doxorubicin as a positive control against the human A549, PC3, HCT116, MCF7, and RPE-1 cell lines.

\begin{tabular}{|c|c|c|c|c|c|}
\hline & $\mathrm{IC}_{50} \pm \mathrm{SD}$ & & & & \\
\hline Sample & MCF7 & A549 & HCT116 & PC3 & RPE-1 \\
\hline 3 & $22.86 \pm 4.7$ & $87.33 \pm 6.34$ & $48.51 \pm 3.1$ & $75.17 \pm 9.26$ & $75.02 \pm 13.8$ \\
\hline 4 & $27.22 \pm 3.9$ & $22.71 \pm 2.83$ & $29.87 \pm 4.2$ & $49.81 \pm 2.71$ & $17.14 \pm 1.1$ \\
\hline 5 & $21.42 \pm 4.5$ & $26.86 \pm 1.67$ & $30.68 \pm 1.63$ & $61.7 \pm 1.26$ & $32.84 \pm 4.05$ \\
\hline 6 & $50.21 \pm 6.8$ & $30.01 \pm 3.3$ & $89.21 \pm 7.9$ & 0.0 & $24.4 \pm 4.12$ \\
\hline 7 & $55.31 \pm 9.7$ & $15.59 \pm 1$ & $29.49 \pm 3.8$ & $37.16 \pm 4.24$ & $62.24 \pm 6.7$ \\
\hline 8 & $10.96 \pm 6.1$ & $66.02 \pm 8$ & $24.25 \pm 1.95$ & $29.88 \pm 2.97$ & $137.5 \pm 12.3$ \\
\hline Doxorubicin & $12.8 \pm 1$ & $0.087 \pm 0.9$ & $2.2 \pm 3.1$ & $6.8 \pm 1.2$ & $0.37 \pm 0.3$ \\
\hline
\end{tabular}

\subsection{Molecular Docking:}


To understand the possible molecular interactions of chalcone $\mathbf{8}$, the molecular simulations were done on two different proteins, histone demethylase enzyme (PLU-1/ JARID1B), which is a transcriptional repressor implicated in breast cancer [21], and the transcriptional co-repressor Carboxy-terminal binding protein1 (CtBP1), which is antiapoptotic protein [22]. The PDB codes were obtained from the protein data bank which are 4LCE and 5FUP for CtBP1 and (PLU-1/JARID1B) respectively. Figures 2 and 3 showed the binding mode of interaction between the standard ligand and chalcone 8 respectively with C-terminal binding protein 1. Chalcone 8 interacted with the active site of CtBP1 with a binding score $S=-20.28$ $\mathrm{Kcal} / \mathrm{mol}$, which is more negative than the standard $(\mathrm{S}=-5.1 \mathrm{Kcal} / \mathrm{mol})$, where there are two types of interactions, one hydrogen bond between oxygen of carbonyl group and Thr128 with bond distance 3.42 $A^{\circ}$, arene-arene interaction between fluoro-benzene ring and Trp318. Figures 4 and 5 demonstrated the type of interactions of standard and chalcone 8 respectively with histone demethylase enzyme. Chalcone 8 interacted with the active site of histone demethylase enzyme with a binding score $S=-10.99 \mathrm{Kcal} / \mathrm{mol}$ comparing to the standard $(S=-9.5 \mathrm{Kcal} / \mathrm{mol})$. It was obvious that chalcone 8 fits the active sites of the protein through two interactions; the first one was aren-cation interaction between benzene ring and Arg98, the second was arene-cation interaction between bromo-benzene ring and Arg98. Based on these findings, we can conclude that chalcone $\mathbf{8}$ may inhibit both tested proteins with a good energy score and hence may suggest a promising cytotoxic activity of chalcone $\mathbf{8}$ against cancer cells via inhibition of antiapoptosis protein. One possible explanation for the observed higher activity of chalcone $\mathbf{8}$ is the halogen content evidenced by its interaction modes via the bromo and fluoro benzenes.

\subsection{Chalcone 8 induces expression of apoptosis-related genes and downregulated anti-apoptotic-, autophagic- and metastasis-related genes in MCF7 cells}

Since our molecular docking suggested a potential role for chalcone $\mathbf{8}$ in apoptosis, we quantified the expression of the mRNA level of key genes involved in apoptosis in MCF7 treated with chalcone $\mathbf{8}$ using qPCR. Cisplatin $\left(\mathrm{IC}_{50}=393.3 \mu \mathrm{M}\right)$ was used as a positive control and untreated MCF7 cells as a negative control. As shown in Fig. 6, the expression mRNA levels of the pro-apoptotic gene BAX, caspase-7, caspase-8, caspase-9, and the tumor suppressor p53 were up-regulated in both chalcone 8-and cisplatintreated MCF7 cells relative to the negative controls. On the other hand, the anti-apoptotic gene $\mathrm{Bcl} 2$ was down-regulated in chalcone 8-and cisplatin-treated MCF7 cells relative to controls. The expression of matrix metalloproteinase 1 (MMP1), which is responsible for the metastasis and proliferation, was downregulated upon treatment with chalcone $\mathbf{8}$ and cisplatin compared to controls. The mRNA expression levels of ATG5 and LC3B, markers of autophagy (type II programmed cell death) were downregulated in chalcone 8-and cisplatin-treated MCF7 cells in comparison to controls. together, this suggests that chalcone $\mathbf{8}$ evoked apoptosis-related genes, and suppressed autophagy- and metastsissrelated factors in MCF7 cells. This is consistent with different reports: licochalcone A and trans-chalcone treatment induced the overexpression of BAX and downregulated the expression of $\mathrm{Bcl} 2$ gene in MCF7 cells [23]. The synthetic chalcone (E)-3-(3, 5-dimethoxyphenyl) 1-(2-hydroxy-5-methoxyphenyl)prop-2-en-1- 
one (2- hydroxy-3',5,5'-trimethoxychalcone stimulated the mitochondrial death pathway through upregulation of caspase-7 and caspase-9 in A549 lung carcinoma cells [24]. Two dihydrotriazinechalcone derivatives exerted an inhibitory effect on the migration of invasive MDA-MB-231 via downregulation of MMP9 expression [25]. On contrast, 3',5'-Diprenylated chalcone ((E)-1-(2-Hydroxy-4-methoxy3,5-diprenyl)(phenyl-3-(3-pyridinyl)-propene-1-one)) induced autophagy in the human leukemia HEL and $\mathrm{K} 562$ cell lines through increasing the expression of LC3A/B[26], this suggests that chalcone derivative have a cell-context dependent effect with the different mode of actions.

\subsection{Chalcone 8 increases cell cycle arrest at the G2/M phase in MCF-7 cells}

Next, we examined whether chalcone 8 had an impact on the cell cycle. As shown in Fig. 7, the percentage of cells in the $\mathrm{G} 2 / \mathrm{M}$ phase was increased from $5.29 \%$ in the untreated control MCF7 cells to $27.29 \%$ in the chalcone 8-treated cells. A lower percentage of chalcone 8-treated cells were observed in the G0-G1 and S phases with $38.29 \%$ and $33.72 \%$ compared with the untreated control with $53.49 \%$ and $41.22 \%$, respectively. Cisplatin as a positive control caused the cell cycle arrest at G2/M with $46.66 \%$. This is in agreement with the action of other chalcone derivatives on the cell cycle [27]. It was found that quinazolinone-chalcone derivative (2-Methyl-3-(3-((E)-3-(3, 4, 5-trimethoxy- phenyl)-2-propenoyl) phenyl)-3, 4-dihydro-4-quinazolinone) inhibited the growth of pancreatic cancer cells (Mia paca-2) through increasing the population of cells in $\mathrm{G} 2 / \mathrm{M}$ phase [28]. Halogenated chalcone derivative ((2E)-3-(3Bromophenyl)-1-(2-hydroxyphenyl) prop-2-en-1- one) showed induction of cell cycle arrest at S and G2/M phases in HCT116 cells [10].

\subsection{Chalcone 8 induces apoptosis in MCF-7 cells}

Next, we examined if chalcone $\mathbf{8}$ induces apoptosis Our flow cytometry analysis indicated that chalcone $\mathbf{8}$ increased the percentage of the Annexin V-positive early-phase apoptotic cells (5.92\%) when compared to the untreated control cells ( $0.78 \%$ ) (Fig. 8). The percentage of late-stage apoptotic cells was $13.8 \%$ relative to the control $(0.36 \%)$. Cisplatin $\left(\mathrm{IC}_{50}=393.3 \mu \mathrm{M}\right)$ was included as a positive control and showed comparable results to those of chalcone $\mathbf{8}$. It was also noticed that there was a slight increase in the percentage of necrotic cells for chalcone 8-treated cells (2.51\%) and cisplatin-treated cells (3.69\%) relative to the untreated control MCF7 cells $(0.51 \%)$. Our results are in line with the apoptosis-induced activity of other chalcones. For examples, 4-fluoro-2', 4'-dihydroxy-chalcone increased the apoptotic percentage in MCF7 cells and 2', 4'- dihydroxy chalcone induced apoptosis in gastric cancer cells (MGC- 803) [29].

\subsection{Chalcone 8 potentiates damage of DNA integrity of in MCF7 cells}

DNA fragmentation is considered a late event that takes place in the apoptosis process [30]. Since we proved that chalcone $\mathbf{8}$ is an apoptosis inducer, we tested its impact on DNA fragmentation. indeed, as shown in Table 2 and Fig. 9, When MCF7 cells were treated with $10.96 \mu \mathrm{M}$ of chalcone 8 for $48 \mathrm{~h}$, the percentage of fragmented DNA was increased approximately by 6-fold $(26.83 \%)$ in comparison to 
negative control MCF7 cells (4.56\%). The effect of chalcone 8 was comparable to that of cisplatin as a positive control (31.61\%). This is consistent with the apoptosis results. A previous report indicated that the novel derivatives of chalcone, imidazolone conjugates, caused DNA damage through p53independent pathway [31]. Further, Pyridyl chalcones induced DNA fragmentation in MCF-7/ ADR and Jurkat cells [32].

Table 2

The percentage of fragmented DNA \pm SD (standard deviation) in MCF7 cells after $48 \mathrm{~h}$ of treatment with chalcone 8. Cisplatin was used as a positive control.

\begin{tabular}{|ll|}
\hline Sample & \% DNA fragmentation \pm SD \\
\hline Chalcone 8/ MCF7 & $26.83 \pm 1.23$ \\
\hline Cisplatin/ MCF7 & $31.61 \pm 1.49$ \\
\hline Control (MCF7 cells) & $4.56 \pm 0.1$ \\
\hline
\end{tabular}

\section{Materials And Methods 3.1. Chemistry}

General. "Melting points were measured with a Stuart melting point apparatus and are uncorrected. The IR spectra were recorded using a FTIR Bruker-vector 22 spectrophotometer as $\mathrm{KBr}$ pellets. The ${ }^{1} \mathrm{H}$ and ${ }^{13} \mathrm{C}$ NMR spectra were recorded in DMSO $-d_{6}$ as a solvent on Varian Gemini NMR spectrometer at 400 $\mathrm{MHz}$ and $100 \mathrm{MHz}$, respectively, using TMS as an internal standard. Chemical shifts are reported as $\delta$ values in ppm. Mass spectra were recorded with a Shimadzu GCMS-QP-1000 EX mass spectrometer in El $(70 \mathrm{eV})$ model. Elemental analyses were performed on a Perkin-Elmer 240 microanalyzer at the Microanalytical Center of Cairo University".

Synthesis of tetrahydro-[1, 2, 4]triazolo[3,4-a]isoquinolin-3-yl)-3-(4-fluorophenyl)prop-2-en-1-one (3-8)

A mixture of 3-acetyl-1-aryltetrahydro-[1, 2, 4]triazolo[3,4-a]isoquinoline 1 (1 mmol) and 4-

fluorobenzaldehyde 2 ( $1 \mathrm{mmol}$ ) was dissolved in $20 \mathrm{~mL}$ ethanol in the presence of potassium hydroxide $(20 \%, 5 \mathrm{~mL})$ at $0-5{ }^{\circ} \mathrm{C}$. The reaction mixture was then stirred at room temperature for $10 \mathrm{~h}$, then poured over cold water containing hydrochloric acid. The solid obtained was then filtered, washed with water, dried, and crystallized from proper solvent to afford chalcones 3-8. 


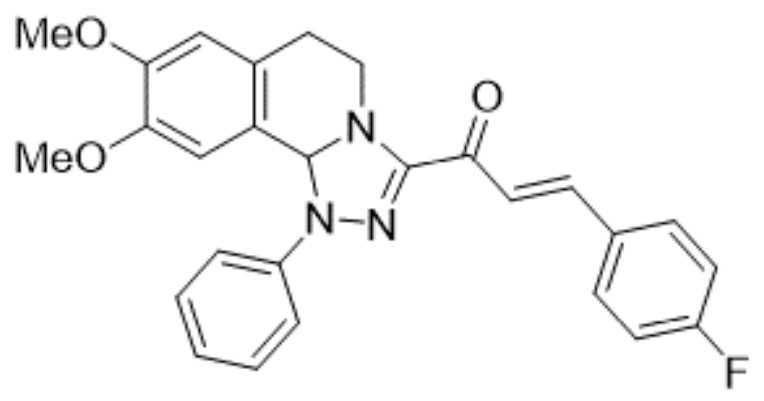

3

(E )-1-(8,9-Dimethoxy-1-phenyl-1,5,6,10b-tetrahydro-[1, 2, 4]triazolo[3,4-a]isoquinolin-3-yl)-3-(4fluorophenyl)prop-2-en-1-one (3)

Yield: (81\%) as a pale-yellow solid (from acetonitrile); m.p 162-164 ${ }^{\circ} \mathrm{C}$. IR $\left(\mathrm{KBr}, \mathrm{cm}^{-1}\right)$ : $1668(\mathrm{CO}) ;{ }^{1} \mathrm{H}$

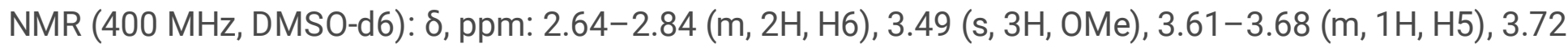
(s, 3H, OMe), 4.20-4.26 (m, 1H, H5), 6.66 (s, 1H, H10b), 6.77 (s, 1H, H7), 6.97-7.88 (m, 12H, H10 + 2 vinyl$\mathrm{H}+\mathrm{Ar}-\mathrm{H}) \mathrm{i}^{13} \mathrm{C}$ NMR (100 MHz, DMSO-d6): $\delta, \mathrm{ppm}: 27.3,41.9,55.7,56.0,78.1,109.3,112.4,115.4,116.6$, $121.6,122.8,127.4,128.8,129.8,131.5,140.6,143.6,147.5,149.0,149.8,162.6,165.1,179.3$; MS (EI): $\mathrm{m} / \mathrm{z}=457\left(\mathrm{M}^{+}\right)$. Anal. Calcd. for $\mathrm{C}_{27} \mathrm{H}_{24} \mathrm{FN}_{3} \mathrm{O}_{3}(457.51): \mathrm{C}, 70.88 ; \mathrm{H}, 5.29 ; \mathrm{N}, 9.18$. Found: $\mathrm{C}, 70.71 ; \mathrm{H}, 5.44$; $\mathrm{N}, 9.32$.

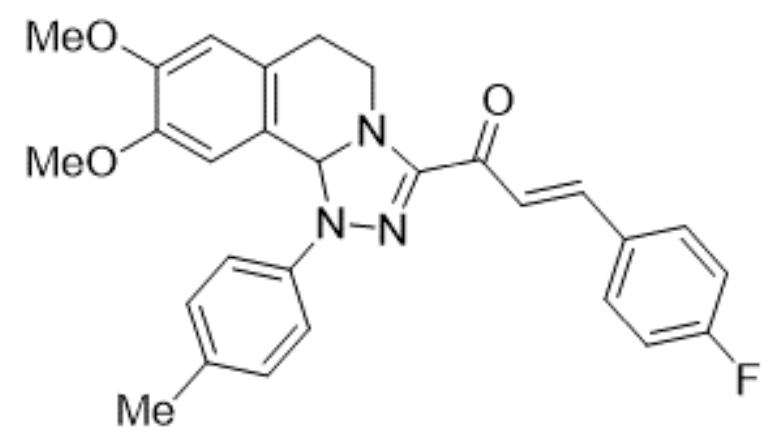

4

(E )-1-(8,9-Dimethoxy-1-( $p$-tolyl)-1,5,6,10b-tetrahydro-11, 2, 4]triazolo[3,4-a]isoquinolin-3-yl)-3-(4fluorophenyl)prop-2-en-1-one (4)

Yield: (89 \%) as a pale-yellow solid (from dioxane); m.p 156-158 ${ }^{\circ} \mathrm{C}$. IR $\left(\mathrm{KBr}, \mathrm{cm}^{-1}\right)$ : 1665 (CO); ${ }^{1} \mathrm{H} \mathrm{NMR}$

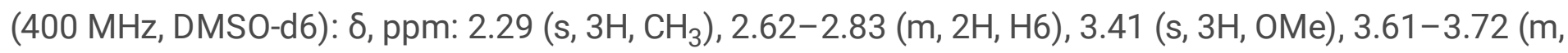
$1 \mathrm{H}, \mathrm{H} 5), 3.87(\mathrm{~s}, 3 \mathrm{H}, \mathrm{OMe}), 4.20-4.53(\mathrm{~m}, 1 \mathrm{H}, \mathrm{H} 5), 6.64(\mathrm{~s}, 1 \mathrm{H}, \mathrm{H} 10 \mathrm{~b}), 6.77(\mathrm{~s}, 1 \mathrm{H}, \mathrm{H7}), 7.18-7.87(\mathrm{~m}, 11 \mathrm{H}$, $\mathrm{H} 10+2$ vinyl-H + Ar-H); ${ }^{13} \mathrm{C}$ NMR (100 MHz, DMSO-d6): $\delta$, ppm:20.8, 27.3, 41.9, 55.8, 56.0, 78.5, 109.5, $112.4,116.6,122.9,126.9,127.3,128.9,130.2,130.7,131.5,140.4,141.3,147.4,149.0,149.6,162.6$, 
165.0, 179.1; $\mathrm{MS}$ (EI): $\mathrm{m} / \mathrm{z}=471\left(\mathrm{M}^{+}\right)$. Anal. Calcd. for $\mathrm{C}_{28} \mathrm{H}_{26} \mathrm{FN}_{3} \mathrm{O}_{3}$ (471.53): C, 71.32; $\mathrm{H}, 5.56 ; \mathrm{N}, 8.91$. Found: C, 71.51; $\mathrm{H}, 5.72 ; \mathrm{N}, 8.79$.

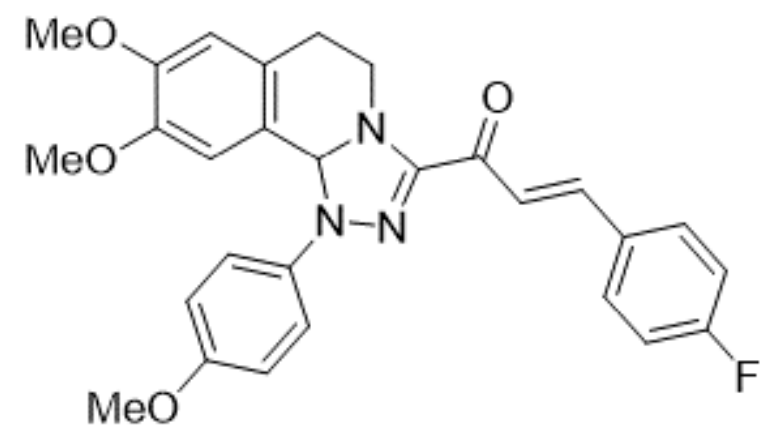

5

(E )-1-(8,9-Dimethoxy-1-(4-methoxyphenyl)-1,5,6,10b-tetrahydro-[1, 2, 4]triazolo[3,4-a]isoquinolin-3-yl)-3-(4fluorophenyl)prop-2-en-1-one (5)

Yield: (78 \%) as a pale-yellow solid (from acetonitrile); m.p 138-140 ${ }^{\circ} \mathrm{C}$. IR $\left(\mathrm{KBr}, \mathrm{cm}^{-1}\right): 1665(\mathrm{CO}) ;{ }^{1} \mathrm{H}$

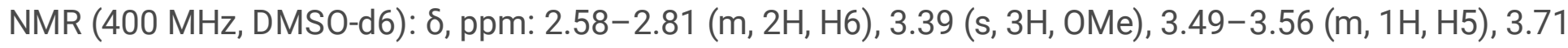
(s, 3H, OMe), 3.75 (s, 3H, OMe), 4.29-4.35 (m, 1H, H5), 6.57 (s, 1H, H10b), $6.73(\mathrm{~s}, 1 \mathrm{H}, \mathrm{H} 7), 6.92(\mathrm{~s}, 1 \mathrm{H}$,

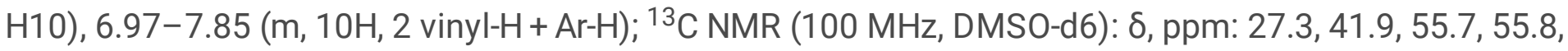
$55.9,79.5,109.8,112.5,115.1,116.6,118.4,123.0,126.7,129.1,131.4,131.7,137.0,140.0,147.3,148.9$, 149.5, 155.2, 162.5, 164.9, 178.8; $\mathrm{MS}(\mathrm{El}): \mathrm{m} / \mathrm{z}=487\left(\mathrm{M}^{+}\right)$. Anal. Calcd. for $\mathrm{C}_{28} \mathrm{H}_{26} \mathrm{FN}_{3} \mathrm{O}_{4}$ (487.53): $\mathrm{C}$, $68.98 ; H, 5.38 ; \mathrm{N}, 8.62$. Found: C, 69.12; H, 5.51; N, 8.83.

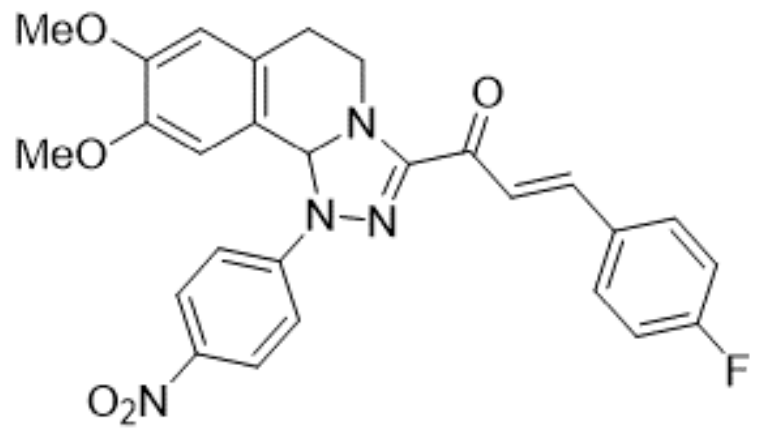

6

(E )-1-(8,9-Dimethoxy-1-(4-nitrophenyl)-1,5,6,10b-tetrahydro-[1, 2, 4]triazolo[3,4-a]isoquinolin-3-yl)-3-(4fluorophenyl)prop-2-en-1-one (6)

Yield: (88 \%) as a pale-yellow solid (from dioxane); m.p 194-196 ${ }^{\circ} \mathrm{C}$. IR $\left(\mathrm{KBr}, \mathrm{cm}^{-1}\right)$ : 1668 (CO); ${ }^{1} \mathrm{H}$ NMR

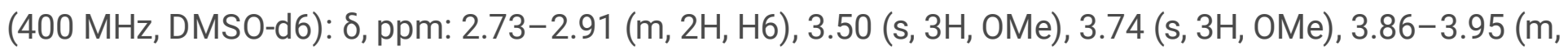


1H, H5), 4.06-4.12 (m, 1H, H5), 6.61 (s, 1H, H10b), 6.87 (s, 1H, H7), 7.07 (s, 1H, H10), 7.28-8.26 (m, 10H,

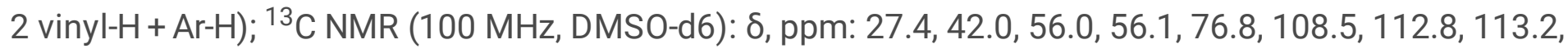
116.7, 122.5, 126.4, 127.1, 128.6, 131.4, 131.9, 139.7, 142.5, 147.7, 148.6, 151.8, 162.9, 165.4, 180.0; MS (El): $\mathrm{m} / \mathrm{z}=502\left(\mathrm{M}^{+}\right)$. Anal. Calcd. for $\mathrm{C}_{27} \mathrm{H}_{23} \mathrm{FN}_{4} \mathrm{O}_{5}$ (502.50): C, 64.54; $\mathrm{H}, 4.61 ; \mathrm{N}, 11.15$. Found: $\mathrm{C}, 64.71 ; \mathrm{H}$, $4.84 ; \mathrm{N}, 11.43$.

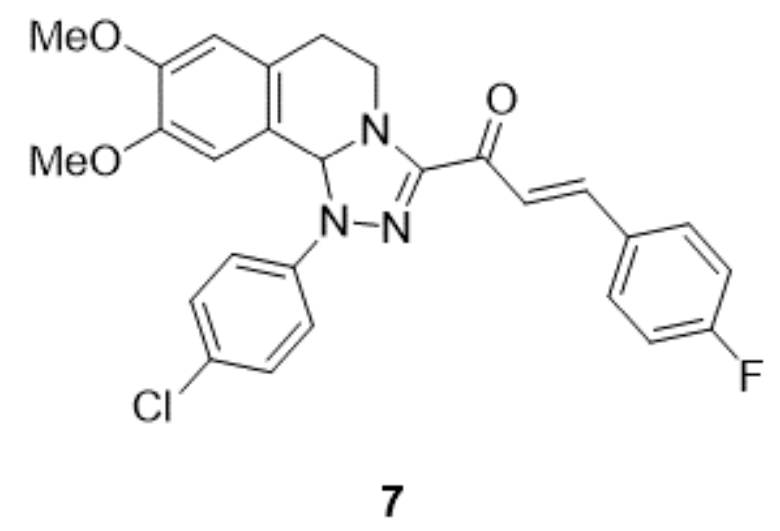

(E )-1-(1-(4-chlorophenyl)-8,9-dimethoxy-1,5,6,10b-tetrahydro-[1, 2, 4]triazolo[3,4-a]isoquinolin-3-yl)-3-(4fluorophenyl)prop-2-en-1-one (7)

Yield: (85 \%) as a pale-yellow solid (from dioxane); m.p $178-180{ }^{\circ} \mathrm{C} . \mathrm{IR}\left(\mathrm{KBr}, \mathrm{cm}^{-1}\right): 1668$ (CO); ${ }^{1} \mathrm{H} \mathrm{NMR}$

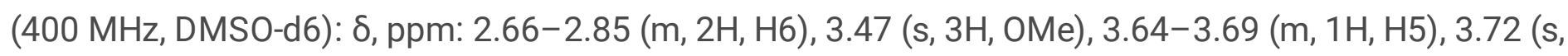
$3 \mathrm{H}, \mathrm{OMe}), 4.13-4.19$ (m, 1H, H5), 6.62 (s, 1H, H10b), 6.80 (s, 1H, H7), 6.93 (s, 1H, H10), 7.26-7.88 (m,

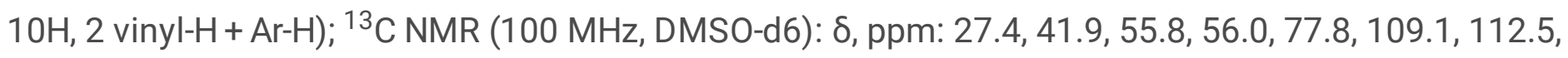
$116.5,116.6,122.7,124.9,127.4,128.8,129.6,131.6,141.1,142.7,147.6,149.1,150.2,156.5,162.7$, 165.1, $179.5 ; \mathrm{MS}(\mathrm{El}): \mathrm{m} / \mathrm{z}=491\left(\mathrm{M}^{+}\right)$. Anal. Calcd. for $\mathrm{C}_{27} \mathrm{H}_{23} \mathrm{ClFN}_{3} \mathrm{O}_{3}$ (491.95): $\mathrm{C}, 65.92 ; \mathrm{H}, 4.71 ; \mathrm{N}, 8.54$. Found: C, 66.15; H, 4.56; N, 8.76.

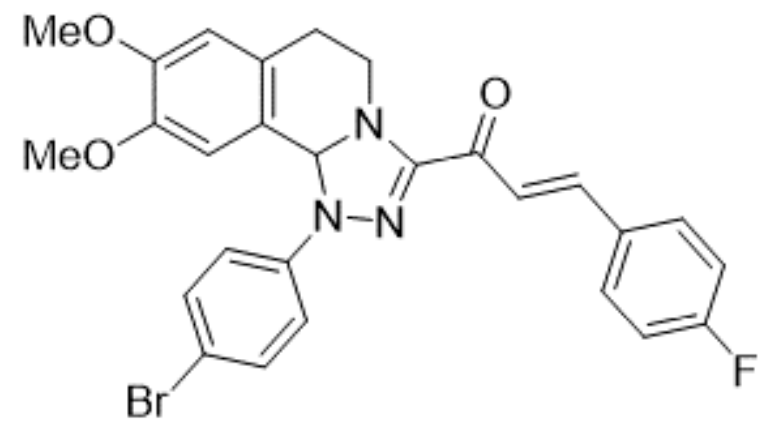

8

(E )-1-(1-(4-Bromophenyl)-8,9-dimethoxy-1,5,6,10b-tetrahydro-[1, 2, 4]triazolo[3,4-a]isoquinolin-3-yl)-3-(4fluorophenyl)prop-2-en-1-one (8) 
Yield: (88\%) as a pale-yellow solid (from dioxane); m.p $174-176{ }^{\circ} \mathrm{C}$. IR $\left(\mathrm{KBr}, \mathrm{cm}^{-1}\right)$ : 1666 (CO); ${ }^{1} \mathrm{H}$ NMR

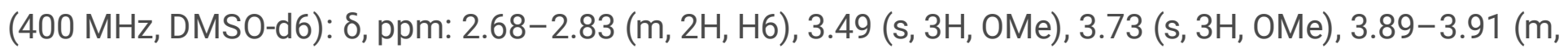
$1 \mathrm{H}, \mathrm{H} 5), 4.12-4.17(\mathrm{~m}, 1 \mathrm{H}, \mathrm{H5}), 6.62$ (s, 1H, H10b), 6.80 (s, 1H, H7), 6.92 (s, 1H, H10), 7.26-7.89 (m, 10H, 2 vinyl-H + Ar-H); ${ }^{13} \mathrm{C}$ NMR (100 MHz, DMSO-d6): $\delta$, ppm: 27.4, 41.9, 55.8, 56.0, 66.8, 77.7, 109.1, 112.5, 112.6, 116.4, 116.7, 116.8, 127.4, 128.8, 131.6, 132.4, 141.1, 143.1, 147.6, 149.1, 150.2, 162.7, 165.2, 179.5; $\mathrm{MS}(\mathrm{El}): \mathrm{m} / \mathrm{z}=536\left(\mathrm{M}^{+}\right)$. Anal. Calcd. for $\mathrm{C}_{27} \mathrm{H}_{23} \mathrm{BrFN}_{3} \mathrm{O}_{3}$ (536.40): $\mathrm{C}, 60.46 ; \mathrm{H}, 4.32 ; \mathrm{N}, 7.83$. Found: C, 60.61; H, 4.57; N, 7.97.

\subsection{Biological assays}

Cell culture

The human HCT-116, MCF7, PC3, A-549, and RPE-1 cell lines were purchased from American Tissue Culture Collection (Rockville, MD, USA). HCT-116, A-549, and MCF7 were maintained in DMEM media, while PC3 cancer cell line was in RPMI-1640 media (Lonza, Biowahittkar, Belgium). The human normal cell line RPE-1 was maintained in DMEM-F12 media. All the media were supplemented with $1 \%$ antibioticantimycotic mixture $(10,000 \mathrm{U} / \mathrm{mL}$ potassium penicillin, $10,000 \mu \mathrm{g} / \mathrm{ml}$ streptomycin sulfate, $25 \mu \mathrm{g} / \mathrm{mL}$ amphotericin B, 1 \% L-glutamine and 10 \% fetal bovine serum (FBS) (Biowest, USA).

\section{MTT cytotoxicity assay}

Cell viability was assessed using MTT [3-(4, 5-dimethylthiazol-2-yl)-2, 5-diphenyltetrazolium bromide] (Bio Basic Canada Inc., Canada). Briefly, cells were seeded into a 96 -well plate at the concentration of $10^{4}$ cells/well and allowed to adhere for $24 \mathrm{~h}$. Different concentrations of the chemical compounds tested at $100,50,25$ and $12.5 \mu \mathrm{M}$ were added to the cell monolayer in triplicate and incubated for $48 \mathrm{~h}$. Subsequently, the medium was aspirated and fresh media with $40 \mu \mathrm{lMTT}(2.5 \mu \mathrm{g} / \mathrm{ml})$ was added to each well and incubated for a further $4 \mathrm{~h}$. Then, $200 \mu \mathrm{l}$ of $10 \%$ sodium dodecyl sulfate (SDS) was added to each well and incubated overnight at $37^{\circ} \mathrm{C}$ to stop the reaction and dissolve the formed formazan crystals. The amount of formazan product was measured at a wavelength of $595 \mathrm{~nm}$ with a reference wavelength of $620 \mathrm{~nm}$ using a microplate reader (Bio-Rad Laboratories, model 3350, USA). Adrinamycin ${ }^{8}$ (doxorubicin) was used as a positive control. Dimethyl sulfoxide (DMSO) was the vehicle used for dissolving all chalcone compounds whereby, its final concentration was less than $0.2 \%$. IC $\mathrm{C}_{50}$ was evaluated using the Prism software program (Graph Pad software incorporated, version 3).

\section{Molecular docking}

The molecular docking studies were performed using the "Molecular Operating Environment (MOE) version 2009.10 release of Chemical Computing Group's". The target compound was drawn using the MOE builder interface and subjected to energy minimization using the included MOPAC. The resulted model was subjected to Systematic Conformational Search where all items were set as default with RMS gradient of $0.01 \mathrm{kcal} / \mathrm{mole}$ and RMS distance of $0.1 \mathrm{~A}^{\circ}$. The X-ray crystallographic structure of the Cterminal binding protein (CtBP) 1 and histone demethylase (PLU-1/ JARID1B) complexed with their 
ligands (PDB ID: 4LCE and 5FUP, respectively) were obtained from the protein data bank. The proteins were prepared for molecular simulations where: Firstly, the hydrogen atoms were added to the target protein with their standard geometry. Then, the water chains and unwanted co-ligands were removed from the protein active site. The active site was determined by MOE alpha site finder and dummy atoms were made from the resulted alpha spheres. Finally, after the self-docking of the prepared protein with the co-crystallized ligand, it was then docked with the target compound to predict the ligand-protein interactions at the active site. The final results obtained in 2D form, which were then visualized through BIOVIA Discovery Studio V6.1.0.15350 in the 3D form.

Quantitative real-time PCR

Total RNA from the chalcone $\mathbf{8}$, and cisplatin-treated MCF7 cells, untreated cells was extracted using the RNA Purification Kit GeneJET (Thermo scientific, ON, Canada). One microgram of RNA was reverse transcribed into complementary DNA (cDNA) using High-Capacity cDNA Reverse Transcription Kit (Thermo scientific, ON, Canada). qPCR was performed using Brilliant SYBR Green qPCR master mix (Applied Biosystems, San Francisco, CA, USA) in a Step One Plus Real-Time PCR System (Applied Biosystems, San Francisco, CA, USA) in a $25 \mu \mathrm{L}$ total reaction volume using $12.5 \mu \mathrm{L}$ of SYBR green master mix, $1 \mu \mathrm{L}$ of each primer (Bax, Bcl2, P53, MMP1, LC3B, ATG5, Caspase- 7, Caspase- 8, and Caspase- 9) with $10 \mathrm{pmol} / \mu \mathrm{L}$ (Qiagen, CA, USA), $2.5 \mu \mathrm{L}$ of $\mathrm{cDNA}$ and $8 \mu \mathrm{L}$ of RNase free water. The thermal profile of PCR started with an initial denaturation at $95^{\circ} \mathrm{C}$ for $10 \mathrm{~min}$, followed by 40 cycles at $94^{\circ} \mathrm{C}$ for $15 \mathrm{sec}, 55^{\circ} \mathrm{C}$ for $30 \mathrm{sec}$ and $60^{\circ} \mathrm{C}$ for $30 \mathrm{sec}$. The relative gene expression was assessed using the $2^{-\triangle \triangle C t}$ method after normalization to expression of glyceraldehyde-3-phosphate dehydrogenase (GAPDH) (Qiagen, CA, USA) (10 pmol/ $\mu \mathrm{L})$. Primer sequences used according to the published literature as follows: Bax 5'-CCACCCTGGTCTTGGATCCAGCCC-3' (forward) and 5'-

GGGCTGGACATTGGACTTCCTCCGGGAGCG-3' (reverse); for Bcl2 5'-ATGTGTGTGGAGAGCGTCAACC-3' (forward) and 5'- TGAGCAGAGTCTTCAGAGACAGCC-3' (reverse); for p53 5'- CTGTCATCTTCTGTCCCTTC3' (forward) and 5'- TGGAATCAACCCACAGCTGCA-3' (reverse); for MMP1 5'-

AGCTAGCTCAGGATGACATTGATG-3' (forward) and 5'- GCCGATGGGCTGGACAG - 3' (reverse); for LC3B 5'AGCAGCATC CAACCAAAATC - 3' (forward) and 5'- CTGTGTCCGTTCCCAACAG-3' (reverse); for ATG5 5'TCTGCACTGTTCATCTAAGGATGCA-3' (forward) and 5'-TCCGATTGATGGCCCAAAACTGGT-3' (reverse); for Caspase-7 5'-GGACCGAGTGCCCACTTATC-3' (forward) and 5'-TCGCTTTGTCGAAGTTCTTGTT-3' (reverse); for Caspase-8 5'- GCCTCCCTCAAGTTCCT-3' (forward) and 5'- CCTGGAGTCTCTGGAATAACA-3' (reverse); for Caspase-9 5'- GGCTGTCTACGGCACAGATGGA-3' (forward) and 5'-CTGGCTCGGGGTTACTGCCAG-3' (reverse); for GAPDH 5'- ACGGATTTGGTCGTATTGGG-3' (forward) and 5'-GATTTTGGAGGGATCTCGC-3' (reverse).

Cell cycle assay:

DNA content was quantitatively assessed using propidium iodide (ab139418, Abcam, Cambridge, UK) and Epics XL-MCL flow cytometer (Beckman Coulter, Miami, FL). Firstly, cells were treated with chalcone 8 at $\mathrm{IC}_{50}$ and incubated for $48 \mathrm{~h}$. Subsequently, cells were collected in a single cell suspension and fixed in 
$70 \%$ ethanol on ice. Then, the cells were centrifuged at $500 \mathrm{xg}$ for 5 minutes, the pellet was washed by 1 $\mathrm{ml} 1 \mathrm{x}$ phosphate-buffered saline (PBS) and the supernatant was discarded. Afterward, the cells were centrifuged, the cell pellet was re-suspended gently in $200 \mu \mathrm{l} 1 \mathrm{X}$ propidium iodide and incubated in dark at $37^{\circ} \mathrm{C}$ for $20-30$ minutes. Finally, the cells were analyzed using a flow cytometer. The cell cycle profile was analyzed using MultiCycle software (Phoenix Flow Systems, San Diego, CA).

Apoptosis assay

Apoptosis was analyzed using the Annexin V-FITC kit (catalog number \# 4830-01K, R\&D Systems, Minneapolis, MN, USA). MCF7 cell line was treated with chalcone 8 at IC ${ }_{50}$ value $10.65 \mu \mathrm{M}$ for $48 \mathrm{~h}$. The cells were centrifuged at approximately $300 \mathrm{xg}$ at room temperature for $10 \mathrm{~min}$. Cells were washed in 500 $\mu \mathrm{l}$ cold $1 \mathrm{X}$ PBS buffer and then were collected by centrifugation as mentioned before. Then, the cells were gently resuspended in the annexin $\mathrm{V}$ incubation reagent comprising of $10 \mu \mathrm{L}$ binding buffer $(10 \mathrm{X})+10 \mu \mathrm{L}$ propidium iodide $+1 \mu \mathrm{L}$ annexin V-FITC $+79 \mu \mathrm{L}$ deionized water. A total of $10^{5}-10^{6}$ cells in $100 \mu \mathrm{L}$ annexin $V$ incubation reagent was incubated in dark at room temperature for 15 min. Finally, $400 \mu \mathrm{l}$ of $1 \mathrm{X}$ binding buffer was added and samples were acquired on flow cytometry.

DNA fragmentation assay

The percentage of fragmented DNA was determined by using Diphenylamine (DPA) assay. The monolayer cell cultures were harvested directly into centrifuge tubes and centrifuged at $300 \times \mathrm{xg}$ at $4^{\circ} \mathrm{C}$ for $10 \mathrm{~min}$. Then, the cell pellet was resuspended in $0.8 \mathrm{~mL}$ of $10 \mathrm{mM} \mathrm{PBS}, \mathrm{pH} \mathrm{7.4,} \mathrm{and} 0.7 \mathrm{~mL}$ of ice-cold lysis buffer (( $5 \mathrm{mM}$ Tris-HCl, $20 \mathrm{mM}$ EDTA, pH 8.0, 0.5\% (v/v) Triton X-100. Afterward, the cell lysate was transferred to microfuge tubes and incubated on ice for $15 \mathrm{~min}$. The lysate was centrifuged at 13,000 $\mathrm{xg}$ at $4^{\circ} \mathrm{C}$ for $15 \mathrm{~min}$ to separate fragmented DNA from high-molecular-weight DNA. The entire supernatant (about $1.5 \mathrm{ml}$ containing fragmented DNA) was transferred to a $5 \mathrm{ml}$ glass tube. The pellet containing intact DNA was resuspended in $1.5 \mathrm{ml}$ TE buffer (1 mM EDTA, $10 \mathrm{mM}$ Tris, $\mathrm{pH}$ 8.0), and again transferred to another $5 \mathrm{ml}$ glass tube. $1.5 \mathrm{~mL}$ of $10 \%$ Trichloroacetic acid (TCA) was added to each tube and incubated for $10 \mathrm{~min}$ at room temperature. The tubes were centrifuged at $500 \mathrm{xg}$ at $4^{\circ} \mathrm{C}$ for $15 \mathrm{~min}$ and the supernatant was discarded. The $10 \%$ TCA precipitates were resuspended in $0.7 \mathrm{ml}$ of $5 \%$ TCA and boiled at $100^{\circ} \mathrm{C}$ for $15 \mathrm{~min}$, then cooled to room temperature, and centrifuged at $300 \mathrm{xg}$ at $4^{\circ} \mathrm{C}$ for $15 \mathrm{~min}$. $0.5 \mathrm{~mL}$ of the supernatant was transferred without disturbing the precipitate to a new glass tube. $1 \mathrm{~mL}$ of DPA was added and incubated overnight at $30^{\circ} \mathrm{C}$. The absorbance was measured at $600 \mathrm{~nm}$. The percentage of DNA fragmentation was calculated using the following equation: \% fragmented DNA = $\mathrm{OD}_{600}$ of the supernatant/ $\left[\mathrm{OD}_{600}\right.$ of the supernatant $+\mathrm{OD}_{600}$ of the pellet] $\times 100$.

\section{Conclusion}

In conclusion, in this study, a novel series of chalcone derivatives (3-8) was synthesized and evaluated as potent anticancer agents against a set of cancer cell lines (MCF7, A549, HCT116, and PC3). The most active compound chalcone $\mathbf{8}$ inhibited proliferation of MCF7 cell line with better potency compared to doxorubicin and exhibited the least cytotoxicity against the normal epithelial cell line RPE-1. Molecular

Page 12/23 
docking showed the inhibitory activity of chalcone 8 against histone demethylase (PLU-1/ JARID1B) and Carboxy-terminal binding protein1 (CtBP1) proteins. Mechanistically, we proved experimentally that chalcone 8 arrested the cell cycle at the G2/M phase and induced apoptosis and DNA fragmentation in MCF7 cells. Furthermore, chalcone 8 upregulated the mRNA expression levels of $B A X, p 53$, and caspase7, caspase-8, and caspase-9, whereas $B c / 2$, the metastasis-related factor $M M P 1$, and the autophagic markers ATG5 and $L C 3 B$ mRNA levels were downregulated. Overall, this study suggests that chalcone 8 may have the potential to serve as a promising therapeutic drug for breast cancer

\section{Declarations}

\section{Acknowledgment}

I. A. Abdelhamid gratefully acknowledge the Alexander von Humboldt Foundation for a research fellowship.

Conflict of Interest: The authors declare that they have no conflict of interest.

Ethical Approval: This article does not contain any studies with human participants or animals performed by any of the authors.

Consent to participate: Not applicable

Consent to publish: Not applicable

\section{Author contribution statements}

N.S.I. carried out and wrote the biochemical experiment part

M.F.M., S.A.I., M.A.E., and S.M.E., suggest and wrote the discussion part related to biochemistry.

H.M.H. and I.A.A suggest and wrote the discussion part related to bis-chalcone derivatives

Funding: Not applicable

Competing Interests: Not applicable

Availability of data and materials: The data are available at request

\section{References}

1. Ferlay, J., Soerjomataram, I., Dikshit, R., Eser, S., Mathers, C., Rebelo, M., ... Bray, F. (2014). Cancer incidence and mortality worldwide: Sources, methods and major patterns in GLOBOCAN 2012. International journal of cancer, 136, 359-386. https://doi.org/10.1002/ijc.29210. 
2. Goldhirsch, A., Winer, E. P., Coates, A. S., Gelber, R. D., Piccart-Gebhart, M., Thürlimann, B., ... Wood, W. C. (2013). Personalizing the treatment of women with early breast cancer: Highlights of the st gallen international expert consensus on the primary therapy of early breast Cancer 2013. Annals of Oncology, 24(9), 2206-2223. https://doi.org/10.1093/annonc/mdt303.

3. Khan, N. S., Khan, P., Ansari, M. F., Srivastava, S., Hasan, G. M., Husain, M., \& Hassan, M. I. (2018). Thienopyrimidine-Chalcone Hybrid Molecules Inhibit Fas-Activated Serine/Threonine Kinase: An Approach to Ameliorate Antiproliferation in Human Breast Cancer Cells. Molecular Pharmaceutics, 15(9), 4173-4189. https://doi.org/10.1021/acs.molpharmaceut.8b00566.

4. Solomon, V. R., \& Lee, H. (2012). Anti-breast cancer activity of heteroaryl chalcone derivatives. Biomedicine \& Pharmacotherapy Pharmacotherapy, 66(3), 213-220. https://doi.org/10.1016/j.biopha.2011.11.013.

5. Rozmer, Z. (2014). Naturally occurring chalcones and their biological activities. Phytochem Rev, 2016(15), 87-120. https://doi.org/10.1007/s11101-014-9387-8.

6. Park, E. J., Park, H. R., Lee, J. S., \& Kim, J. (1998). Licochalcone A: An inducer of cell differentiation and cytotoxic agent from Pogostemon cablin. Planta Medica, 64(5), 464-466. https://doi.org/10.1055/s-2006-957485.

7. Ko, H. H., Tsao, L. T., Yu, K. L., Liu, C. T., Wang, J. P., \& Lin, C. N. (2003). Structure-activity relationship studies on chalcone derivatives: The potent inhibition of chemical mediators release. Bioorganic and Medicinal Chemistry, 11(1), 105-111. https://doi.org/10.1016/S0968-0896(02)00312-7.

8. Yang, G.-F., \& Huang, X. (2006). Development of Quantitative Structure-Activity Relationships and Its Application in Rational Drug Design. Current Pharmaceutical Design, 12(35), 4601-4611. https://doi.org/10.2174/138161206779010431.

9. Jain, U. K., Bhatia, R. K., Rao, A. R., Singh, R., Saxena, A. K., \& Sehar, I. (2014). Design and development of halogenated chalcone derivatives as potential anticancer agents. Tropical Journal of Pharmaceutical Research, 13(1), 73-80. https://doi.org/10.4314/tjpr.v13i1.11.

10. Dias, T. A., Duarte, C. L., Lima, C. F., Proença, M. F., \& Pereira-Wilson, C. (2013). Superior anticancer activity of halogenated chalcones and flavonols over the natural flavonol quercetin. European Journal of Medicinal Chemistry, 65, 500-510. https://doi.org/10.1016/j.ejmech.2013.04.064.

11. Al-Awadi, N. A., Abdelhamid, I. A., Al-Etaibi, A. M., \& Elnagdi, M. H. (2007). Gas-phase pyrolysis in organic synthesis: Rapid green synthesis of 4-quinolinones. Synlett, (14), 2205-2208. https://doi.org/10.1055/s-2007-985573.

12. Al-Awadi, N. A., Ibrahim, M. R., Abdelhamid, I. A., \& Elnagdi, M. H. (2008). Arylhydrazonals as the aldehyde component in Baylis-Hillman reactions. Tetrahedron, 64(35), 8202-8205. https://doi.org/10.1016/j.tet.2008.06.026.

13. Darwish, E. S., Abdelhamid, I. A., Nasra, M. A., Abdel-Gallil, F. M., \& Fleita, D. H. (2010). A one-pot Biginelli synthesis of 6-unsubstituted 5-aroylpyrimidin-2(1H)- ones and 6-acetyl-1,2,4-triazin-3(2H)ones. Helvetica Chimica Acta, 93(6), 1204-1208. https://doi.org/10.1002/hlca.200900355. 
14. Mohamed, M. F., Mohamed, M. S., Shouman, S., Fathi, M. M., \& Abdelhamid, I. A. (2012). Synthesis and biological evaluation of a novel series of chalcones incorporated pyrazole moiety as anticancer and antimicrobial agents. Applied biochemistry and biotechnology, 168(5), 1153-1162. https://doi.org/10.1007/s12010-012-9848-8.

15. Salama, S. K., Mohamed, M. F., Darweesh, A. F., Elwahy, A. H. M., \& Abdelhamid, I. A. (2017).

Molecular docking simulation and anticancer assessment on human breast carcinoma cell line using novel bis(1,4-dihydropyrano[2,3-c]pyrazole-5-carbonitrile) and bis(1,4dihydropyrazolo[4',3':5,6]pyrano[2,3-b]pyridine-6-carbonitrile) derivatives. Bioorganic Chemistry, 71, 19-29. https://doi.org/10.1016/J.BIOORG.2017.01.009.

16. Mohamed, M. F., Ibrahim, N. S., Elwahy, A. H. M., \& Abdelhamid, I. A. (2018). Molecular Studies on Novel Antitumor Bis 1,4-Dihydropyridine Derivatives Against Lung Carcinoma and their Limited Side Effects on Normal Melanocytes. Anti-Cancer Agents in Medicinal Chemistry, 18(15), 2156-2168. https://doi.org/10.2174/1871520618666181019095007.

17. Mohamed, M. F., Abdelmoniem, A. M., Elwahy, A. H. M., \& Abdelhamid, I. A. (2018). DNA fragmentation, cell cycle arrest, and docking study of novel bis spiro-cyclic 2-oxindole of pyrimido[4,5-b]quinoline-4,6-dione derivatives against breast carcinoma. Current Cancer Drug Targets, 18(4), 372-381. https://doi.org/10.2174/1568009617666170630143311.

18. Mohamed, M. F., Hassaneen, H. M., \& Abdelhamid, I. A. (2018). Cytotoxicity, molecular modeling, cell cycle arrest, and apoptotic induction induced by novel tetrahydro-[1,2,4]triazolo[3,4-a]isoquinoline chalcones. European Journal of Medicinal Chemistry, 143(1), 532-541. https://doi.org/10.1016/J.EJMECH.2017.11.045.

19. Elwan, N. M., Abdelhadi, H. A., Abdallah, T. A., \& Hassaneen, H. M. (1996). Synthesis of $[1,2,4]$ triazolo[3,4-a]isoquinolines and pyrrolo[2,1-a]isoquinolines using a-keto hydrazonoyl halides. Tetrahedron, 52(10), 3451-3456. https://doi.org/10.1016/0040-4020(96)00024-5.

20. Hassaneen, H. M., Hassaneen, H. M. E., Mohammed, Y. S., \& Pagni, R. M. (2011). Synthesis, Reactions and Antibacterial Activity of 3-Acetyl[1,2,4]triazolo[3,4-a]isoquinoline Derivatives using Chitosan as Heterogeneous Catalyst under Microwave Irradiation. Zeitschrift für Naturforschung B, 66(3), 299310. https://doi.org/10.1515/znb-2011-0313.

21. Molecular Cell, 25, 801-812. https://doi.org/10.1016/j.molcel.2007.03.001.

22. Zhang, Q., Yoshimatsu, Y., Hildebrand, J., Frisch, S. M., \& Goodman, R. H. (2003). Homeodomain interacting protein kinase 2 promotes apoptosis by downregulating the transcriptional corepressor CtBP. Cell, 115(2), 177-186. https://doi.org/10.1016/S0092-8674(03)00802-X.

23. Biomedicine and Pharmacotherapy, 85, 425-433. https://doi.org/10.1016/j.biopha.2016.11.047.

24. Gil, H., Koh, D., Lim, Y., Han, Y., \& Young, S. (2018). Bioorganic \& Medicinal Chemistry Letters induces unfolded protein response-mediated apoptosis in A549 lung cancer cells. Bioorganic \& Medicinal Chemistry Letters, 28(17), 2969-2975. https://doi.org/10.1016/j.bmcl.2018.07.003.

25. KB signaling pathway. Food and Chemical Toxicology, 116, 238-248. https://doi.org/10.1016/j.fct.2018.04.003. 
26. Zhang, Y., Wen, Z., Wan, K., Yuan, D., \& Zeng, X. (2018). Biomedicine \& Pharmacotherapy A novel synthesized 3 ', 5 ' -diprenylated chalcone mediates the proliferation of human leukemia cells by regulating apoptosis and autophagy pathways. Biomedicine \& Pharmacotherapy, 106, 794-804. https://doi.org/10.1016/j.biopha.2018.06.153.

27. Hsu, Y. L., Kuo, P. L., Tzeng, W. S., \& Lin, C. C. (2006). Chalcone inhibits the proliferation of human breast cancer cell by blocking cell cycle progression and inducing apoptosis. Food and Chemical Toxicology, 44(5), 704-713. https://doi.org/10.1016/j.fct.2005.10.003.

28. Journal of Solid Tumors, 5(2), 73-85. https://doi.org/10.5430/jst.v5n2p73.

29. Bioorganic \& Medicinal Chemistry, 20(1), 25-33. https://doi.org/10.1016/j.bmc.2011.11.042.

30. Journal of Enzyme Inhibition and Medicinal Chemistry, 33(1), 727-742.

https://doi.org/10.1080/14756366.2018.1450749.

31. Cancer Cell International, 11, 11. https://doi.org/10.1186/1475-2867-11-11.

32. Cancer Chemotherapy and Pharmacology, 46(4), 305-312. https://doi.org/10.1007/s002800000160.

\section{Scheme 1}

Scheme 1 can be found in the Supplemental Files.

\section{Figures}




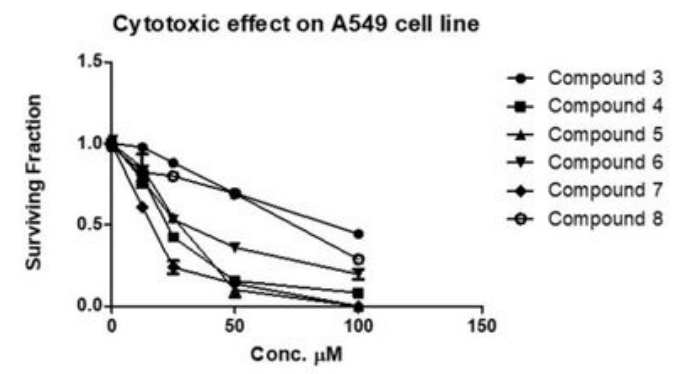

Cytotoxic effect on MCF7 cell line

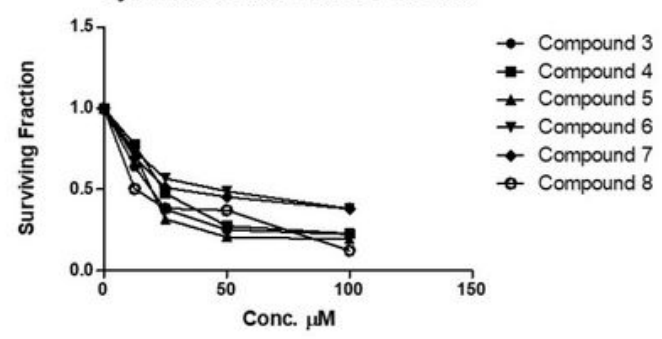

Cytotoxic effect on HCT116 cell line

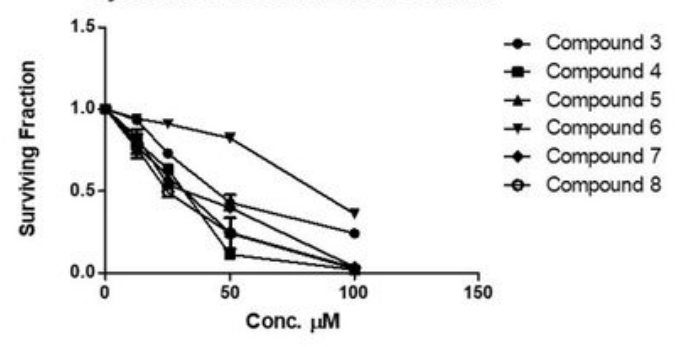

Cytotoxic effect on PC3 cell line

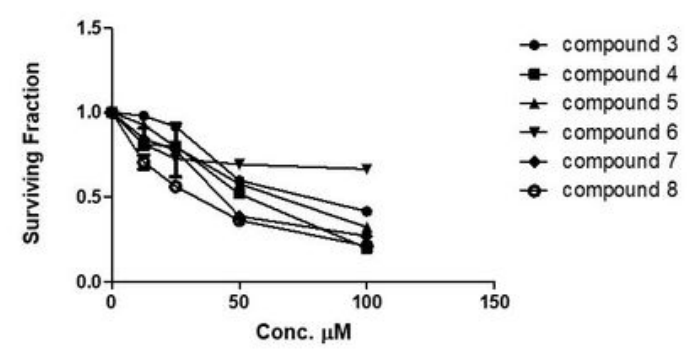

Cytotoxic effect on RPE-1 cell line

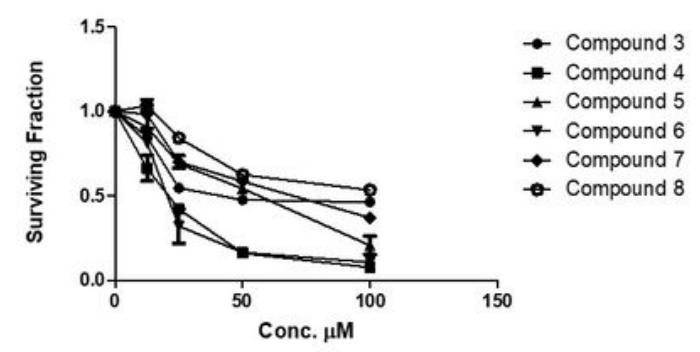

\section{Figure 1}

Cytotoxic effect of halogenated chalcone derivatives 3-8 against the human A549, PC3, HCT116, MCF7, and RPE-1 cell lines using MTT assay. The cell lines were subjected to different concentrations of halogenated chalcone derivatives 3-8 for $48 \mathrm{~h}$. 

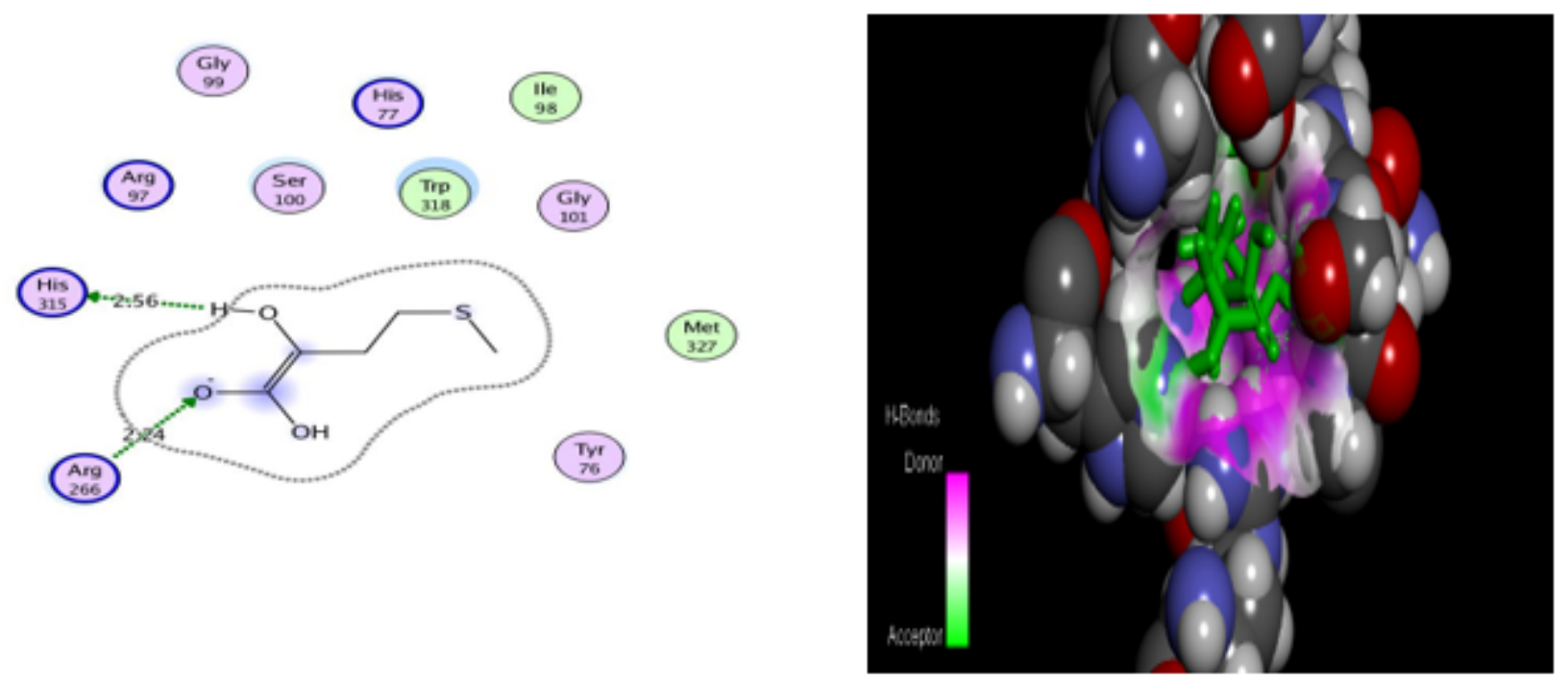

Figure 2

2D and 3D structures of the standard co-crystallized ligand of Carboxy-terminal binding protein 1 (CtBP1).
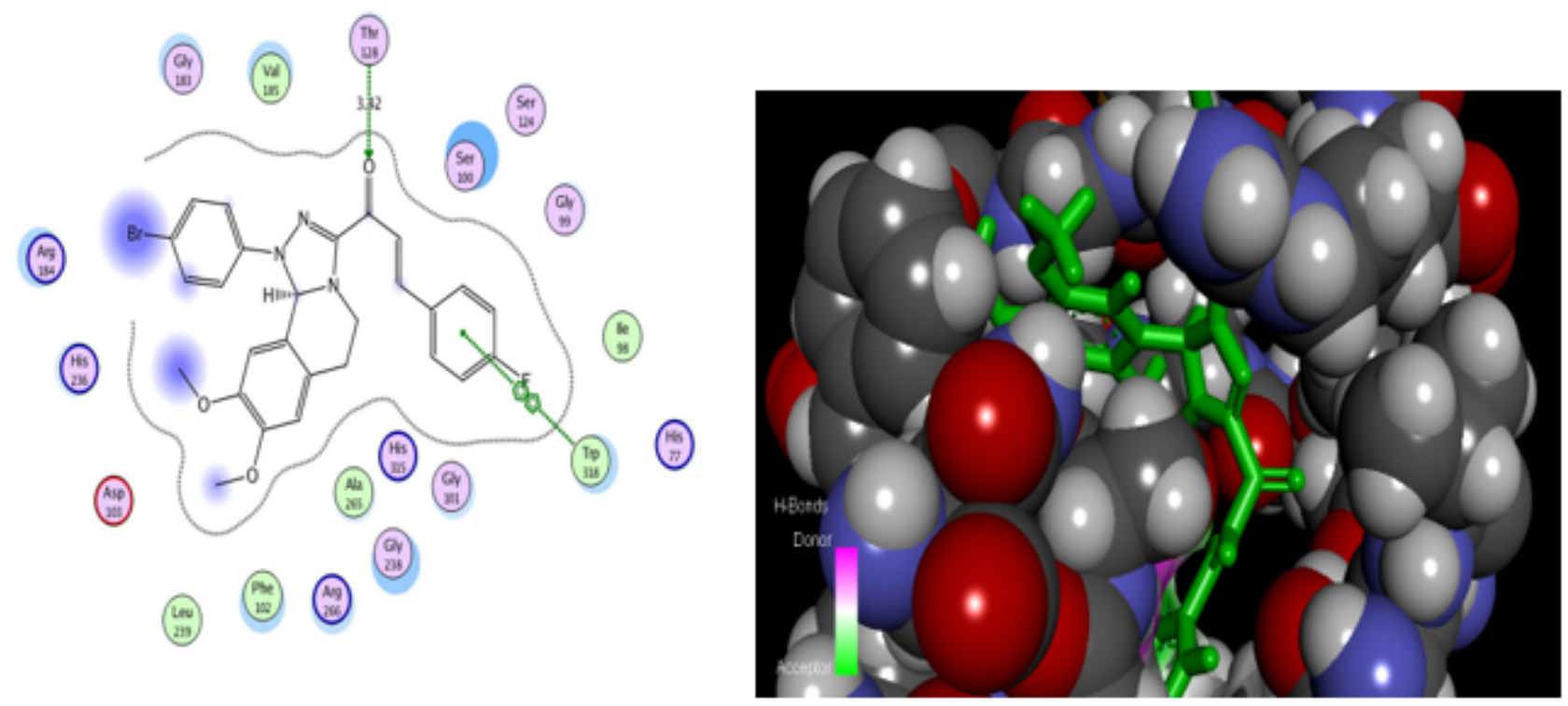

Figure 3

2D and 3D structures of the binding model of the active site of C-terminal binding protein1 (CtBP1) and chalcone 8. 


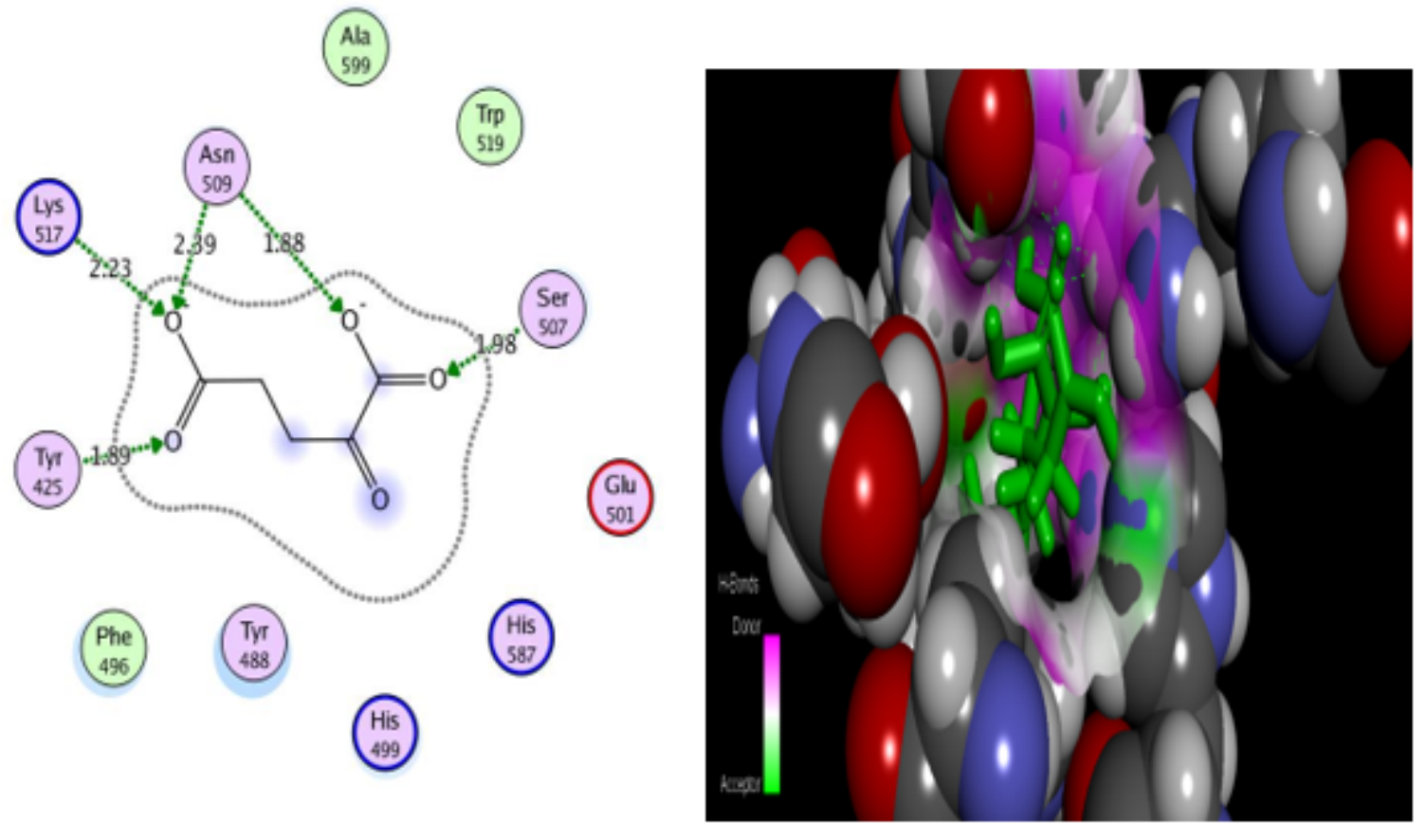

Figure 4

2D and 3D structures of the standard co-crystallized ligand of histone demethylase (PLU-1/ JARID1B).

(8)

(2) (5:<smiles>[C+]=[C-]</smiles>

(충
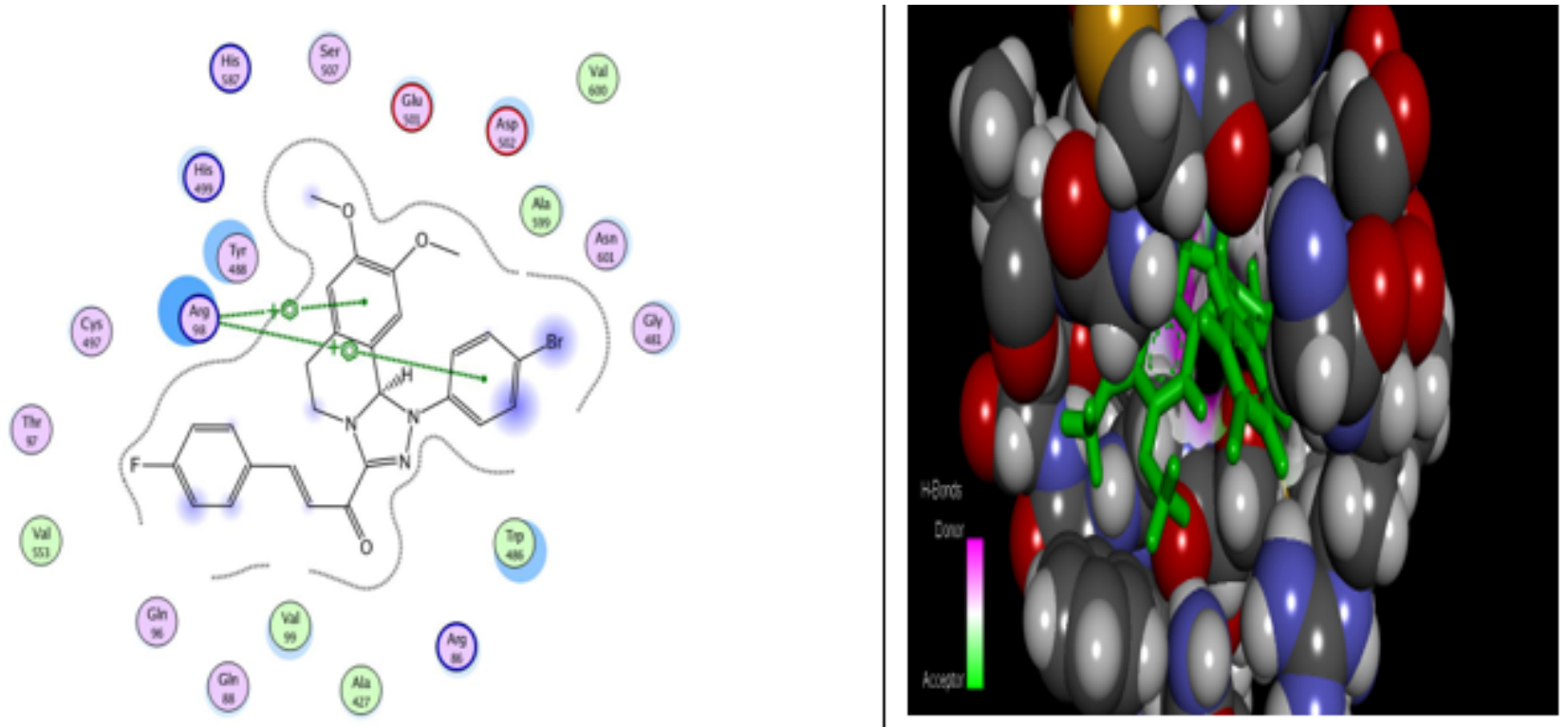

Figure 5

2D and 3D structures of the binding model of the active site of histone demethylase JARID1B with chalcone 8. 


\section{Relative expression (fold/ $\beta$-actin)}

Relative expression (fold/ $\beta$ actin)

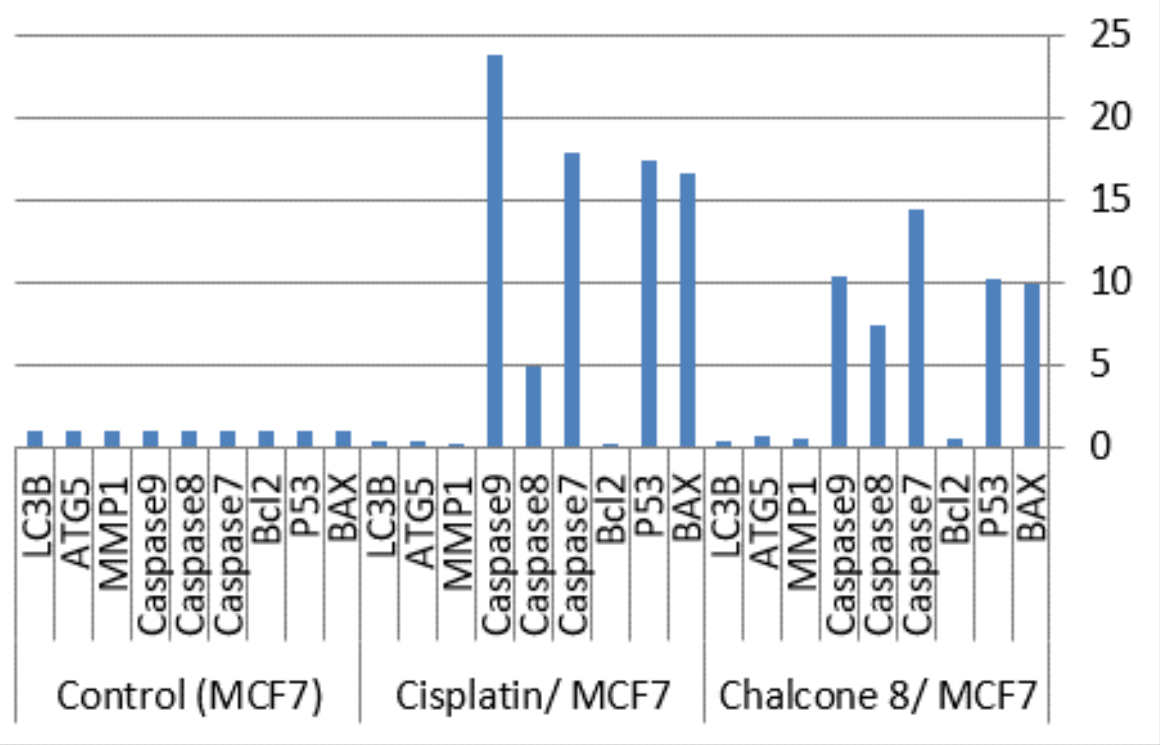

Figure 6

Relative mRNA expression levels of BAX, P53, Bcl2, Caspase 7, Caspase 8, Caspase 9, MMP1, ATG5, and LC3B as determined by qPCR. MCF7 cells treated with chalcone 8 or cisplatin or left untreated were lysed and total cellular RNA extracted was reverse transcribed into cDNA Fold expression was determined by the 2- $\Delta \Delta C$ t method after normalization to the expression of $\beta$-actin as an endogenous control. 

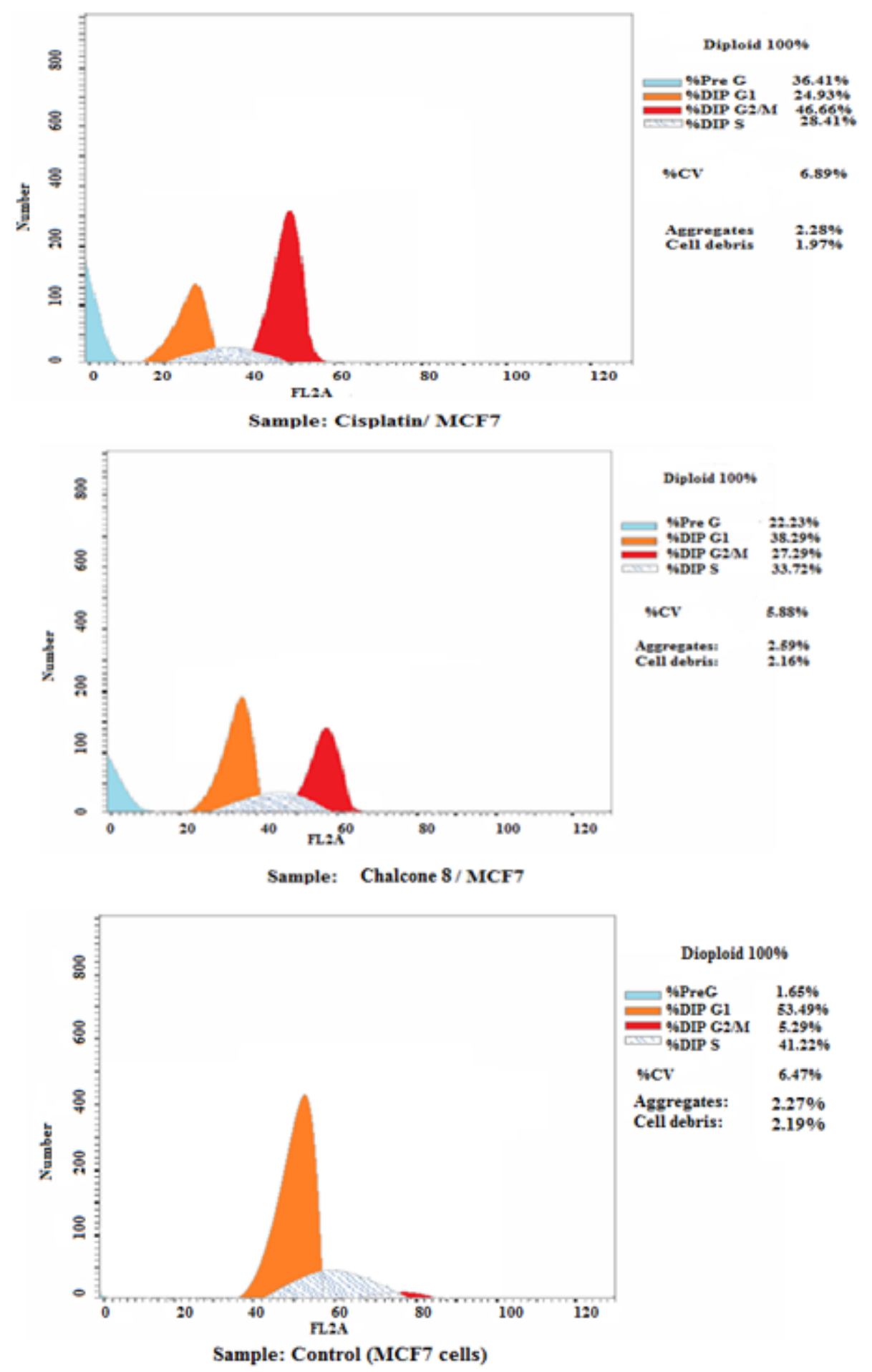

\section{Figure 7}

Effect of chalcone 8 on cell cycle in MCF7 cells. Chalcone 8 was added to MCF7 cells for $48 \mathrm{~h}$, and cells were trypsinized, fixed, and stained with propidium iodide. Treated and untreated MCF7 cells were subjected to the flow cytometric analysis of the cell cycle profile. Cisplatin was used as a positive control. 


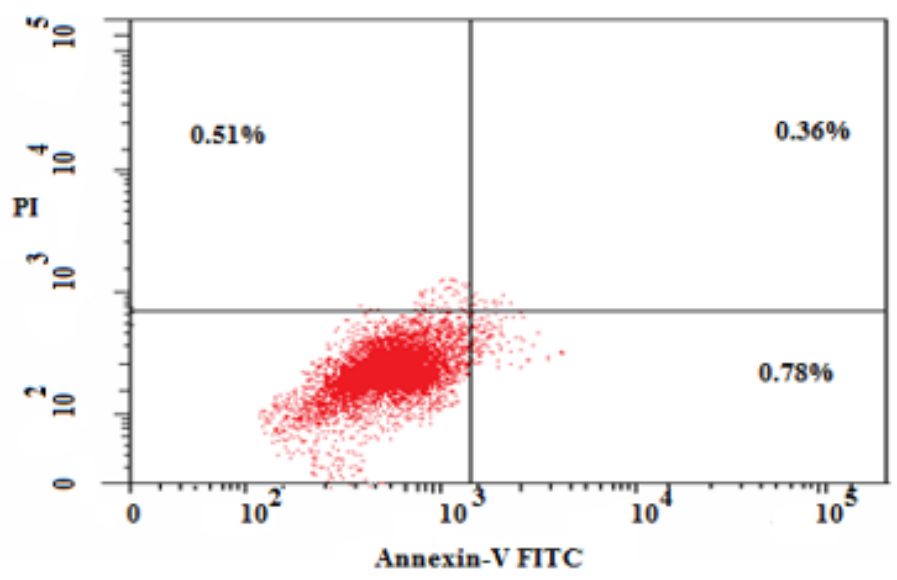

Sample: Control (MCF7 cells)

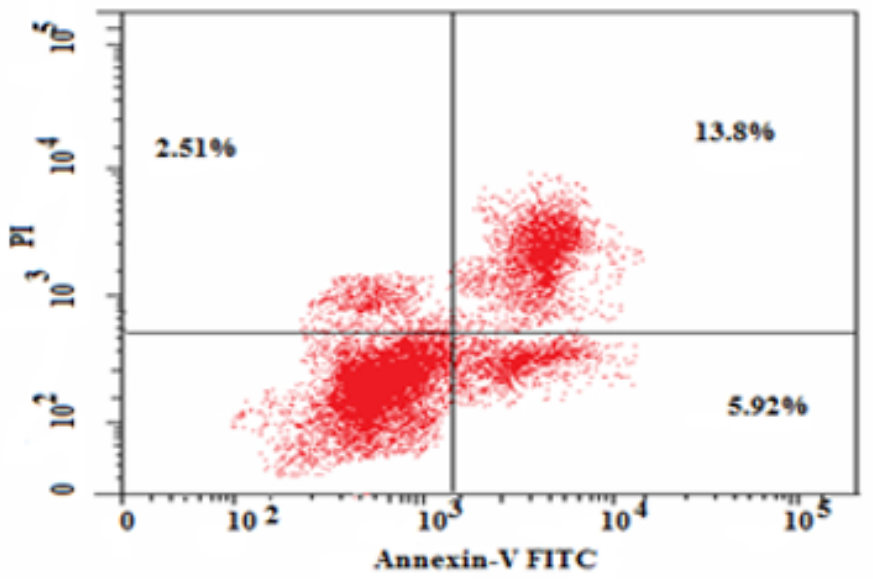

Sample: Chalcone 8/MCF7

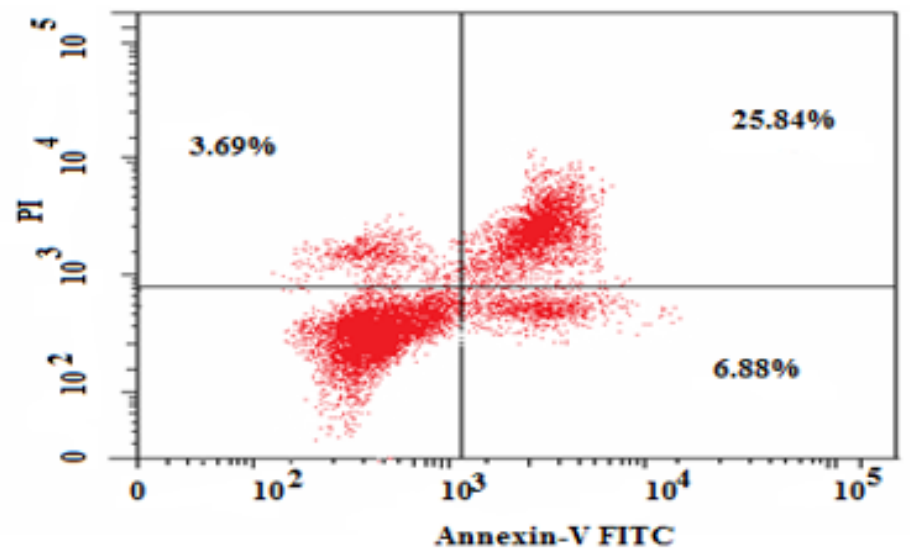

Sample: Cisplatin/ MCF7

\section{Figure 8}

Flow cytometric analysis of apoptosis in control and Chalcone-8-treated MCF7 cells after $48 \mathrm{~h}$. Cisplatin was used as a positive control. 


\section{DNA fragmentation}

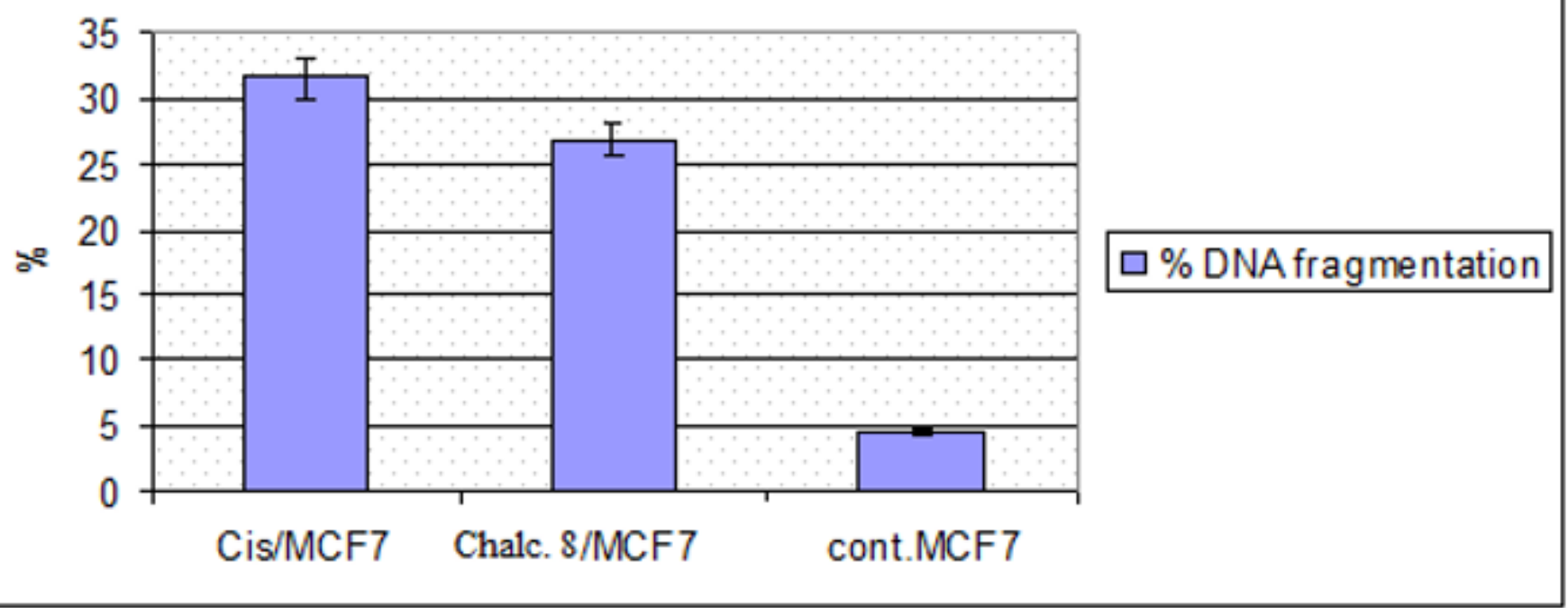

Figure 9

Chalcone 8 treatment augments DNA damage in MCF-7. Quantitative analysis of fragmented DNA in MCF7 cells treated with chalcone 8. Cisplatin was used as a positive control and untreated MCF7 cells as a negative control. Data represent the mean \pm SD.

\section{Supplementary Files}

This is a list of supplementary files associated with this preprint. Click to download.

- Scheme1.png

- GraphicalAbstract.docx 